\title{
Fertility, survival, and conformation of Montbéliarde $\times$ Holstein and Viking Red $\times$ Holstein crossbred cows compared with pure Holstein cows during first lactation in 8 commercial dairy herds
}

\author{
A. R. Hazel, ${ }^{1}$ B. J. Heins, and L. B. Hansen \\ Department of Animal Science, University of Minnesota, St. Paul 55108
}

\begin{abstract}
Montbéliarde $(\mathrm{MO}) \times$ Holstein $(\mathrm{HO})$ and Viking Red $(\mathrm{VR}) \times \mathrm{HO}$ crossbred cows were compared with pure HO cows in 8 large, high-performance dairy herds in Minnesota. All cows calved for the first time from December 2010 to April 2014. Fertility and survival traits were calculated from records of insemination, pregnancy diagnosis, calving, and disposal that were recorded via management software. Body condition score and conformation were subjectively scored once during early lactation by trained evaluators. The analysis of survival to $60 \mathrm{~d}$ in milk included $536 \mathrm{MO} \times \mathrm{HO}, 560 \mathrm{VR} \times$ $\mathrm{HO}$, and 1,033 $\mathrm{HO}$ cows during first lactation. Cows analyzed for other fertility, survival, and conformation traits had up to $13 \%$ fewer cows available for analysis. The first service conception rate of the crossbred cows (both types combined) increased $7 \%$, as did the conception rate across the first 5 inseminations, compared with the HO cows during first lactation. Furthermore, the combined crossbred cows $(2.11 \pm 0.05)$ had fewer times bred than HO cows $(2.30 \pm 0.05)$ and 10 fewer $\mathrm{d}$ open compared with their $\mathrm{HO}$ herdmates. Across the 8 herds, breed groups did not differ for survival to $60 \mathrm{~d}$ in milk; however, the superior fertility of the crossbred cows allowed an increased proportion of the combined crossbreds $(71 \pm 1.5 \%)$ to calve a second time within 14 mo compared with the HO cows $(63 \pm 1.5 \%)$. For survival to second calving, the combined crossbred cows had $4 \%$ superior survival compared with the HO cows. The $\mathrm{MO} \times \mathrm{HO}$ and $\mathrm{VR} \times \mathrm{HO}$ crossbred cows both had increased body condition score $(+0.50 \pm 0.02$ and $+0.25 \pm 0.02$, respectively) but shorter stature and less body depth than $\mathrm{HO}$ cows. The $\mathrm{MO} \times \mathrm{HO}$ cows had less set to the hock and a steeper foot angle than the $\mathrm{HO}$ cows, and the $\mathrm{VR} \times \mathrm{HO}$ cows had more set
\end{abstract}

Received March 2, 2017.

Accepted July 7, 2017.

${ }^{1}$ Corresponding author: haze0025@umn.edu to the hock with a similar foot angle to the HO cows. The combined crossbred cows had less udder clearance from the hock than $\mathrm{HO}$ cows, more width between both front and rear teats, and longer teat length than the HO cows; however, the frequency of first-lactation cows culled for udder conformation was uniformly low $(<1 \%)$ across the breed groups.

Key words: crossbreeding, Montbéliarde, Viking Red, fertility

\section{INTRODUCTION}

Breeding goals of dairy cattle throughout the world have heavily emphasized production traits. However, a negative genetic correlation between production and fertility has been documented (Philipsson et al., 1994; Berry et al., 2014). Phenotypically, Holstein (HO) cows have deteriorated in fertility commensurate with increases in production (Walsh et al., 2011). Therefore, fertility and longevity have gradually received more emphasis over time in selection indices around the world (Miglior et al., 2005).

A steep decline in phenotypic fertility for $\mathrm{HO}$ cows may have plateaued at a low level during the early 2000s (Berry et al., 2014), but the plateau may be mostly attributable to environmental intervention rather than a reversal of the genetic trend for $\mathrm{HO}$ cows (VanRaden et al., 2014). Norman et al. (2015) reported decreases in days open (DO) and calving interval from 2004 to 2014 among pure HO cows in the United States; however, the results were not caused by increased conception rate (CR), which was only $34 \%$ for first services in 2014. Also, a continual increase of the mean inbreeding coefficient may have impeded phenotypic improvement for fertility because inbreeding is more detrimental for functional traits, such as fertility, health, and survival, than other traits (Falconer and Mackay, 1996). The average inbreeding coefficient of $\mathrm{HO}$ calves born early in 2017 in the United States was 7.11\% (Council on Dairy Cattle Breeding, 2017). Heterosis results when distinct breeds of cattle are crossed; therefore, some 
commercial dairy producers have turned to crossbreeding to improve fertility (Walsh et al., 2008). Sørensen et al. (2008) summarized the heterosis for fertility traits of 2-breed crosses including $\mathrm{HO}$ and concluded that about $10 \%$ heterosis should be expected for fertility traits when other breeds are crossed with HO cows. Furthermore, the marked advantage in fertility for crossbred cows over HO cows may be attributable to additive genetic effects of non-HO breeds (Sørensen, 2007; Norman et al., 2009; Dezetter et al., 2015) in addition to heterosis.

Culling decisions for individual cows are heavily affected by production, fertility status, age, health status, stage of lactation, cull value of cows, value of replacements, or a combination of these factors (Gröhn et al., 2003). Diseases of cows have a major effect on longevity, and Kyntäjä (2013) documented fewer health treatments for Viking Red (VR) cows than for HO cows in Finland. Dairy producers in European countries have recorded health treatments, including lameness, for many years in France (Bourrigan et al., 2016) and the Nordic countries (Emanuelson, 2013). Therefore, selection for improved health was possible for the Montbéliarde (MO) and VR breeds, and, as a result, these breeds may be well suited for crossbreeding with the HO breed.

Montbéliarde cows in France had approximately 13\% less mortality than French HO cows in 2005 (Raboisson et al., 2011), and VR cows had $22 \%$ less mortality than HO cows in Sweden (Alvåsen et al., 2012). Advantages for additive genetic effects of the MO and VR breeds for mortality combined with 10 to $15 \%$ heterosis for longevity from crossbreeding (Sørensen et al., 2008) has resulted in interest in 3-breed rotational crossbreeding using the MO, VR, and HO breeds. Despite the global prominence of the $\mathrm{HO}$ breed over the past $30 \mathrm{yr}$, pure HO cows rank poorly for survival compared with other dairy breeds (Hare et al., 2006), and this has generated interest by dairy producers in crossbreeding. Cow survival is a growing concern of the general public for animal welfare.

The HO breed has been heavily selected for large frame size over time, and the genetic trend for increased stature, strength, and body depth of HO cows continues (VanRaden et al., 2014) despite a negative weight on frame size since 2000 in the US net merit index (VanRaden and Cole, 2014). The continuous increase in mean body size of $\mathrm{HO}$ cows is concerning because larger body size of cows results in increased costs for health treatments (Becker et al., 2012), reduced feed efficiency because of increased maintenance requirements of large-framed cows (VandeHaar et al., 2016), and reduced survival of cows (Hansen et al., 1999; Van-
Raden and Cole, 2014). Selection for angularity of HO cows via selection for final score type has resulted in reduction of BCS (Hansen, 2000), and the phenotypic relationship of low BCS and poor fertility and health in HO cows is well documented (Roche et al., 2009; Walsh et al., 2011).

The MO and VR breeds may complement the HO breed for crossbreeding because the selection goals of these 2 breeds have included fertility and health alongside production of milk solids; however, the HO breed focused more on production at the expense of fertility and health. The VR breed ignored body condition, and the MO breed selected for greater body condition in their selection programs over time. The $\mathrm{MO} \times \mathrm{HO}$ crossbred cows evaluated by Hazel et al. (2013, 2014) had similar stature to their pure HO herdmates. Also, $\mathrm{VR} \times \mathrm{HO}$ cows may have reduced body size compared with $\mathrm{HO}$ cows because pure VR cows are $6.5 \mathrm{~cm}$ shorter than HO cows in Denmark, Finland, and Sweden (H. Stålhammar, VikingGenetics, Skara, Sweden; personal communication). Advantages of crossbred cows over HO cows for fertility and survival may have resulted from the increased BCS of crossbreds (Pryce and Harris, 2006; Walsh et al., 2008; Hazel et al., 2014). Studies of pure HO cows have found negligible relationships between rump, leg, and udder conformation with metabolic and reproductive diseases (Zwald et al., 2004), but HO cows with shallow udders are superior for udder health (Zwald et al., 2004; Carlström et al., 2016a).

The objective of this study was to compare phenotypes of fertility, survival, and conformation from first lactations of $\mathrm{MO} \times \mathrm{HO}$ and $\mathrm{VR} \times \mathrm{HO}$ crossbred cows with pure $\mathrm{HO}$ cows in a designed study. The same 2-breed crossbreds were previously compared with pure $\mathrm{HO}$ cows for production and calving traits during first lactation (Hazel et al., 2017).

\section{MATERIALS AND METHODS}

\section{Experimental Design}

Descriptions of Herds and Cows Enrolled. A 10-yr designed study of crossbreeding was initiated between March and September of 2008 in 8 high-performance dairy herds in Minnesota. A total of 3,550 pure $\mathrm{HO}$ virgin heifers as well as mostly first- or second-lactation cows were offered by the herd owners as foundation females to initiate the study. Cows in all herds were housed in 4- or 6-row freestall confinement facilities and fed a TMR during lactation. The mean herd size in May 2016 was 791 cows, and the herds had a weighted mean production level of $13,918 \mathrm{~kg}$ of milk, $510 \mathrm{~kg}$ of fat, and $430 \mathrm{~kg}$ of protein from Minnesota 
DHI. The 8 herds had general satisfaction with most of their herd statistics, including mean level of production; however, they participated in the study because they sought to reduce the need for health treatments and to minimize fertility aids and thereby reduce labor costs. The herds comingled the crossbred and HO cows at all times, and they grouped cows for housing only by age, stage of lactation, and fertility status. The herds used the same management regimens across the breed groups, including approaches for health treatments and culling.

Mating Design. Researchers for this study assigned the foundation females offered by herd owners to either the crossbred or HO breed groups. The assignment of the foundation $\mathrm{HO}$ females to the breed groups was based on age and sire for heifers and was based on parity, sire, and projected mature equivalent milk production for cows. At least 150 of the foundation pure HO females in each herd were mated to $\mathrm{HO}$ bulls through successive generations to maintain a control group of $\mathrm{HO}$ cows for comparison with crossbreds. Also, at least 100 of the foundation $\mathrm{HO}$ females in each herd were mated to MO or VR bulls to initiate a 3-breed rotation for crossbreeding. The resulting 2-breed crossbred progeny were inseminated to the third breed (i.e., MO $\times \mathrm{HO}$ cows were mated to $\mathrm{VR}$ bulls and the $\mathrm{VR} \times$ HO cows were mated to MO bulls) to create 3-breed crossbred cattle. Foundation pure HO and all subsequent generations of heifers and cows were individually mated to AI bulls by 2 genetic advisors employed by Minnesota Select Sires Co-op Inc. (St. Cloud, MN). Both crossbred and pure $\mathrm{HO}$ cows were correctively mated for conformation, and heifers were correctively mated based on conformation scores of their dam when possible. Each heifer and cow was assigned to 2 or 3 potential mates for use across multiple inseminations. Inbreeding protection was provided for matings of $\mathrm{HO}$ bulls to pure HO heifers and cows.

Cows in this study were either 2-breed crossbred or pure HO cows sired by proven AI bulls that had high rank for genetic merit within the 3 breeds. Bulls were chosen by herd owners in consultation with the 2 genetic advisors. The HO bulls were proven AI sires marketed by Select Sires Inc. (Plain City, $\mathrm{OH}$ ). Herd owners were asked to select $\mathrm{HO}$ bulls that ranked within the top $10 \%$ of all available bulls in the United States for the net merit index (VanRaden and Cole, 2014). For the MO and VR bulls, all semen was imported into the United States by Creative Genetics of California (Oakdale, CA). The bulls chosen ranked highly among bulls available in the United States based on the French ISU index (O. S. Montbéliarde, 2016) and the Nordic total merit index (Nordic Cattle Genetic Evaluation,
2016), which are the national selection indices for the MO and VR breeds, respectively. The selection indices used by the 3 breeds included traits for production, fertility, survival, udder health, and conformation. Also, the semen from the AI bulls was processed in certified semen processing laboratories of Select Sires Inc., Umotest (Ceyzériat, France), and Viking Genetics (Randers, Denmark) for HO, MO, and VR bulls, respectively. The VR breed resulted from combining the previously separate genetic improvement programs of the Swedish Red, Finnish Ayrshire, and Danish Red breeds, and these 3 breeds historically shared genetic material and applied similar selection goals. Sires of cows in this study were selected for use during the years 2008 to 2011, and the individual sires of cows were reviewed by Hazel et al. (2017).

Initial Data Editing. Across the 8 herds, 1,275 crossbred and 1,351 HO females had the opportunity to calve for a first time between December 2010 and April 2014 and to lactate at least $305 \mathrm{~d}$ in their first lactation. Of these, 333 females left the herds before first calving, 28 calved or aborted after April 2014, and another 59 initiated their first lactations with abortion. Abortions were defined as calvings with gestation lengths less than $260 \mathrm{~d}$. These edits resulted in 1,105 crossbred cows $(539 \mathrm{MO} \times \mathrm{HO}$ and $566 \mathrm{VR} \times \mathrm{HO}$ combined) and 1,101 HO first-lactation cows available for analysis. Hazel et al. (2017) provided the numbers of cows for each of the $4 \mathrm{yr}$ of first calving and for each of the 8 herds in the study.

\section{Trait Descriptions}

Fertility. Reproductive protocols varied from herd to herd as well as over time within herds and were not recorded for this study. However, herd owners were requested to manage cows in the same manner at all times across breed groups. All the herds had large numbers of cows and used group housing; therefore, reproductive protocols were likely applied uniformly across breed groups. The days to first breeding (DFB) was the number of days from calving to first insemination. Firstservice CR (FSCR) was the proportion of cows that became pregnant after a single insemination divided by the cows that were bred for the first time. Pregnancy status was ascertained by a subsequent insemination, by palpation or ultrasound, or by subsequent calving. The overall CR consisted of the proportion of successful inseminations divided by the total number of inseminations during first lactation, including cows that did not conceive by the end of the study. However, only the first 5 inseminations that occurred from 45 to 305 DIM were considered to eliminate individual cows that 
may have been treated preferentially by herd owners. Times bred was the number of inseminations, and the maximum number of inseminations was set to 5 for cows with more than 5 inseminations. The final fertility trait was DO, which was defined as the number of days from first calving to pregnancy.

Survival. Survival was recorded as a binary trait and was defined as survived or not for each of 4 time intervals. Survival to 60 DIM was the proportion of cows that survived in the herds to 60 DIM divided by the total cows that calved a first time. Subsequent calving within 14 mo and subsequent calving within 17 mo were the proportion of cows that calved a second time within 14 or 17 mo, respectively, divided by all cows that calved a first time. Survival to second calving was the proportion of cows that calved a second time divided by the total number of cows that calved for a first time.

BCS and Conformation. The BCS and conformation were evaluated once during first lactation from 2 to 110 DIM, and cows were mostly scored in early lactation ( $32 \pm 0.5 \mathrm{DIM})$ by the 2 genetic advisors across the years of the study. The BCS was subjectively assigned on a 1 -to- 5 scale $(1=$ thin, $5=$ obese $)$ in increments of 0.25 (Ferguson et al., 1994). The 10 conformation traits included stature (STA; height at the withers), body depth (BD), strength (STR), rump angle (RA), leg set (LS; side view), foot angle (FA), udder clearance (UC; relative to hock), front teat width (FTW), rear teat width $(\mathbf{R T W})$, and teat length (TL; front teats). Conformation traits were scored from 1 to 9 in increments of 1 , and scores were assigned independent of age or stage of lactation (Select Sires Inc.). Linear scores were subjectively assigned; however, definitions of scores for some linear traits corresponded with a measurement objective. Table 1 describes the scales used for conformation traits. For all conformation traits, a score of 5 was the biological midpoint and did not necessarily represent a mean score.

\section{Final Editing and Analysis}

Fertility. The number of cows analyzed varied for each of the 5 fertility traits because edits were applied separately to each trait. For DFB, cows that were first bred before 45 DIM $(n=2)$, cows that left before first insemination $(\mathrm{n}=116)$, and cows bred by a natural service bull $(\mathrm{n}=3)$ were removed. Cows retained were assigned to herd-year-season (HYS) of first calving, and HYS was defined as 4-mo periods (January to April, May to August, and September to December) within each herd that likely best reflected climatic conditions in Minnesota. Each herd had up to 11 HYS of first calving across the years of the study. The data were further edited to permit a valid comparison of crossbreds and HO cows within each HYS, and those edits were conducted separately for each trait. To remain in the data, each HYS was required to contain at least 3 crossbred $(\mathrm{MO} \times \mathrm{HO}$ and $\mathrm{VR} \times \mathrm{HO}$ breed groups combined) and $3 \mathrm{HO}$ cows; therefore, a total of 6 combined crossbred and $63 \mathrm{HO}$ cows that did not meet this criterion were removed from the analysis for DFB. Other HYS with small numbers of cows in the $\mathrm{MO} \times \mathrm{HO}$ or $\mathrm{VR} \times \mathrm{HO}$ breed group were combined within herds. The HYS that contained fewer than 3 of either $\mathrm{MO} \times \mathrm{HO}$ or $\mathrm{VR} \times \mathrm{HO}$ cows were combined with adjacent HYS. After edits, the number of cows analyzed for DFB included 1,046 crossbred (both types combined) and $970 \mathrm{HO}$ cows.

For FSCR, 2 HO cows with a first insemination before 45 DIM were removed, but these 2 cows had subsequent inseminations after 45 DIM and were included for overall CR. All other edits were identical for FSCR and overall CR, and they included the removal of cows that did not remain in the herd to be bred or to be verified for pregnancy after a first service $(\mathrm{n}=132)$, the removal of cows that were bred to a natural service bull or to an AI bull that did not conform to the mating design of the study $(n=22)$, and the removal of cows

Table 1. Descriptions of minimum (1), intermediate (5), and maximum (9) scores for linear conformation traits

\begin{tabular}{llll}
\hline Trait $^{1}$ & 1 & 5 & 9 \\
\hline Stature & Short $(\leq 129 \mathrm{~cm})$ & Intermediate $(140 \mathrm{~cm})$ & Tall $(\geq 150 \mathrm{~cm})$ \\
Body depth & Shallow & Proportionate to body length & Deep \\
Strength & Narrow & Intermediate & Wide \\
Rump angle & Reverse slope (pins $13 \mathrm{~cm}$ higher than hips) & Level pins and hips & Slope (pins $13 \mathrm{~cm} \mathrm{lower} \mathrm{than} \mathrm{hips)}$ \\
Leg set & Posty & Slight set & Sickle \\
Foot angle & Low $\left(\leq 25^{\circ}\right)$ & Intermediate $\left(45^{\circ}\right)$ & Steep $\left(\geq 65^{\circ}\right)$ \\
Udder clearance & Low $(\geq 5 \mathrm{~cm}$ below hocks $)$ & Intermediate $(5 \mathrm{~cm}$ above hocks $)$ & High $(\geq 15 \mathrm{~cm}$ above hocks $)$ \\
Front teat width & Wide & Central & Close \\
Rear teat width & Wide $(\leq 3 \mathrm{~cm})$ & Central & Close \\
Teat length & Short $(\geq 8 \mathrm{~cm})$ & Long $(\geq 8 \mathrm{~cm})$ & Intermediate $(6 \mathrm{cos})$ \\
\hline
\end{tabular}

${ }^{1}$ All traits were subjectively scored; however, measurement goals are provided for stature, rump angle, foot angle, udder clearance, and teat length. 
in HYS that had fewer than the 3 crossbred and $3 \mathrm{HO}$ contemporaries $(\mathrm{n}=75)$. A total of 1,027 crossbred cows were compared with 948 (for FSCR) and 950 (for overall CR) HO cows.

The cows removed from the analysis of times bred included cows first bred before 45 DIM $(\mathrm{n}=2)$, cows that did not remain in the herd to a first insemination $(\mathrm{n}=116)$, cows bred to a natural service bull or an AI bull that did not conform to the mating design before fifth service $(n=17)$, and cows calving in HYS with fewer than 3 crossbred and $3 \mathrm{HO}$ cows $(\mathrm{n}=69)$. Following these edits, 1,043 crossbred and $959 \mathrm{HO}$ cows were compared for times bred.

For DO, cows exceeding $250 \mathrm{~d}(\mathrm{n}=217)$ were set to 250 d (VanRaden et al., 2004), which is the method used for genetic evaluation in the United States. Also, DO were required to be at least 50 DIM, and 18 crossbred and $3 \mathrm{HO}$ cows with DO of 45 to $49 \mathrm{~d}$ were set to $50 \mathrm{~d}$. Cows were required to complete 250 DIM to be included in the analysis (VanRaden et al., 2004); therefore, 103 crossbred and 132 HO cows were removed. Cows bred by natural service bulls before 250 DIM $(\mathrm{n}=11)$ and cows calving in HYS with less than 3 crossbred and 3 HO cows $(\mathrm{n}=65)$ were removed. To provide an example of the distribution of crossbred and HO cows across herds, Table 2 shows the number of cows analyzed for DO within each of the herds by breed group.

The analysis of DFB, FSCR, overall CR, times bred, and DO included the fixed effects of HYS of first calving, breed of cow (crossbred or HO), and breed group $(\mathrm{MO} \times \mathrm{HO}$ nested within crossbred, $\mathrm{VR} \times \mathrm{HO}$ nested within crossbred, or HO). Sire of cow nested within breed group was a random effect. Additionally, FSCR and overall $\mathrm{CR}$ included the random effect of service sire nested within breed group of sire (i.e., MO or VR sire nested within crossbred). The MIXED procedure of SAS (release 9.4; SAS Institute Inc., Cary, NC) was used to obtain least squares means and to conduct the ANOVA for DFB, times bred, and DO. Because conception is a binary trait, the GLIMMIX procedure of SAS was used to determine probability of significance for contrasts between breed of cow and between breed groups for FSCR and overall CR. The $P$-values for the comparison of breed groups were subjected to the Bonferroni correction to account for multiple comparisons. First, HO was designated the control to correct the $P$-values that compared $\mathrm{MO} \times \mathrm{HO}$ and $\mathrm{VR} \times \mathrm{HO}$ with HO cows. Second, no control group was designated to correct the $3 P$-values that included the comparison of $\mathrm{MO} \times \mathrm{HO}$ with $\mathrm{VR} \times \mathrm{HO}$ cows.

Survival. For survival to 60 DIM, the cows sold for dairy purposes $(n=4)$ during the first $60 \mathrm{~d}$ of first lactation were removed from the analysis. Also, the
Table 2. Distribution of cows analyzed for days open by herd

\begin{tabular}{lccc}
\hline Herd & $\begin{array}{c}\text { Pure } \\
\text { Holstein }\end{array}$ & $\begin{array}{c}\text { Montbéliarde } \\
\times \text { Holstein }\end{array}$ & $\begin{array}{c}\text { Viking Red } \\
\times \text { Holstein }\end{array}$ \\
\hline A & 127 & 36 & 40 \\
B & 85 & 28 & 23 \\
C & 73 & 45 & 42 \\
D & 182 & 84 & 88 \\
E & 136 & 130 & 139 \\
F & 113 & 90 & 88 \\
G & 97 & 25 & 41 \\
H & 88 & 42 & 53 \\
Total & 901 & 480 & 514 \\
Mean (SE) & $113(12)$ & $60(13)$ & $64(13)$ \\
\hline
\end{tabular}

HYS of first calving were edited in the same manner as they were for fertility for all survival traits, and cows $(\mathrm{n}=73)$ that calved during HYS without at least 3 crossbred and $3 \mathrm{HO}$ cows were removed. After all edits, 1,096 crossbred and 1,033 $\mathrm{HO}$ cows were analyzed for survival to 60 DIM.

For analysis of subsequent calving within 14 mo, cows sold for dairy purposes during the first 14 mo of first lactation $(\mathrm{n}=30)$ were removed from analysis. In total, 1,082 crossbred and 1,021 HO cows were available for analysis of subsequent calving within 14 mo. The edits for subsequent calving within 17 mo were identical to subsequent calving within 14 mo, except 2 additional crossbred cows were sold for dairy purposes between 14 and 17 mo after first calving. For survival to second calving, cows sold for dairy purposes during first lactation were removed $(\mathrm{n}=32)$. Also, $8 \mathrm{HO}$ cows completed at least 17 mo of their first lactation but had not yet completed their entire first lactation at the time of this analysis (mean DIM $=647 \pm 42$ ). These cows were removed from analysis because their final status for survival to second lactation was unknown.

The analysis of all survival traits included the fixed effects of HYS of first calving, breed of cow (crossbred or $\mathrm{HO})$, and breed group of cow $(\mathrm{MO} \times \mathrm{HO}$ nested within crossbred, VR $\times$ HO nested within crossbred, or HO). Furthermore, the random effect of sire of cow nested within breed group was included. Least squares means were obtained from the MIXED procedure of SAS, and the significance of contrasts was obtained from the GLIMMIX procedure of SAS because survival is a binary trait. Orthogonal contrasts for each type of 2-breed crossbred versus $\mathrm{HO}$ cows were evaluated in the same manner as fertility traits and used the Bonferroni correction for comparisons between breed groups.

BCS and Conformation. Across breed groups, 134 cows were excluded from analysis of BCS because they either left the herd before scoring or did not have BCS recorded. Cows were assigned to HYS of first calving for both BCS and conformation in the same man- 
ner as fertility and survival traits. The same criteria were used for editing and combining of HYS of first calving. A total of 1,040 crossbred and $956 \mathrm{HO}$ cows were analyzed for BCS. The edits were identical for all 10 conformation traits. In total, 95 cows that calved for a first time were not scored for conformation. The analysis of conformation traits included 1,051 crossbred and $983 \mathrm{HO}$ cows after all edits.

The uniform model used for the analysis of BCS and conformation included the fixed effects of HYS of first calving, breed of cow (crossbred or HO), and breed group of cow. Furthermore, the effect of DIM at scoring was included as a class variable, and the 4 DIM classes consisted of 2 to 19,20 to 39,40 to 59 , and 60 to $110 \mathrm{~d}$. Finally, the random effect of sire nested within breed group was included. The MIXED procedure of SAS was used to obtain the least squares means and to perform the ANOVA. A Bonferroni correction was used to evaluate orthogonal contrasts between breed groups as previously described.

\section{RESULTS AND DISCUSSION}

\section{Fertility}

The effect of HYS of first calving was highly significant for DFB, FSCR, overall CR, and times bred; however, HYS did not differ for DO. The crossbred cows (both types combined) were superior $(P<0.01)$ to the HO cows for all 5 of the fertility traits during first lactation (Table 3). The combined crossbred cows $(69 \pm 0.4 \mathrm{~d})$ were bred $2 \mathrm{~d}$ sooner $(P<0.01)$ after first calving than their pure HO herdmates $(71 \pm 0.4 \mathrm{~d})$. Most first inseminations resulted from enrollment in a timed AI protocol, and this may explain the small differences of the least squares means between breed groups and the small standard errors for DFB.

The combined crossbred cows had increased $(P<$ $0.01)$ FSCR and overall CR $(45 \pm 1.7 \%$ and $45 \pm 1.4 \%$, respectively) compared with the $\mathrm{HO}$ cows $(38 \pm 1.7 \%$ and $38 \pm 1.3 \%$, respectively; Table 3 ). The VR $\times \mathrm{HO}$ crossbred cows bred to MO bulls $(47 \pm 2.4 \%)$ had $9 \%$ increased $(P<0.01)$ FSCR compared with the HO cows; however, the MO $\times \mathrm{HO}$ cows bred to VR bulls were similar to HO cows for FSCR. Potential differences between the 2 types of crossbreds were inconsequential for FSCR or overall CR because the 2 types of crossbreds did not differ $(P>0.98)$ for either trait. Differences between crossbreds and HO cows for FSCR in the current study were similar to those reported by Heins et al. (2006b) from a California field study, in which $\mathrm{MO} \times \mathrm{HO}(31 \pm 3.0 \%)$ had increased $(P<0.05)$ FSCR. In both Heins et al. (2006b) and the current study, the crossbred cows had advantages from both the heterosis of the cows and the heterosis of their embryos compared with the pure $\mathrm{HO}$ cows and their pure HO embryos.

The times bred for the combined crossbred cows (2.11 $\pm 0.05)$ were fewer $(P<0.01)$ than the times bred for the HO cows $(2.30 \pm 0.05)$ during first lactation (Table $3)$. The difference was from the $\mathrm{MO} \times \mathrm{HO}$ cows being inseminated fewer times $(P<0.01)$ because the $\mathrm{VR} \times$ HO cows were not different $(P=0.12)$ from their HO herdmates for times bred. Results in this study concur with those of Malchiodi et al. (2014), who found MO $\times$ HO (2.02) and VR $\times$ HO (2.14) had fewer times bred than first-lactation HO cows (2.53).

The combined crossbred cows $(115 \pm 2.0 \mathrm{~d})$ had 10 fewer DO than the HO cows $(125 \pm 2.1 \mathrm{~d})$ during first lactation. The $\mathrm{MO} \times \mathrm{HO}(-12 \mathrm{~d})$ and $\mathrm{VR} \times \mathrm{HO}(-8$ d) crossbred cows did not differ $(P=0.84)$ from each other for DO; however, both types of crossbreds had decreased $(P<0.02)$ DO compared with the HO cows in first lactation (Table 3). VanRaden et al. (2004) reported that $14 \%$ of DO records exceeded $250 \mathrm{~d}$ in a national evaluation of $\mathrm{HO}$ cows enrolled in DHI, and this is very similar to the $13 \%$ of records set to $250 \mathrm{~d}$ for the pure HO cows in this study. However, a chisquared test indicated that fewer $(P<0.05)$ crossbred cows (10\%) surpassed 250 DO than HO cows; therefore,

Table 3. Least squares means and standard errors for days to first breeding (DFB), first-service conception rate (FSCR), overall conception rate (CR), times bred (up to 5), and days open (DO) for both crossbred groups (pooled), Montbéliarde $\times$ Holstein crossbreds, and Viking Red $\times$ Holstein crossbreds compared with pure Holstein cows during first lactation

\begin{tabular}{|c|c|c|c|c|c|c|c|c|c|c|c|c|}
\hline Trait & \multicolumn{3}{|c|}{ Pure Holstein } & \multicolumn{3}{|c|}{ Both crossbred groups } & \multicolumn{3}{|c|}{ Montbéliarde $\times$ Holstein } & \multicolumn{3}{|c|}{ Viking Red $\times$ Holstein } \\
\hline Overall CR (\%) & 950 & 38 & 1.3 & 1,027 & $45^{* *}$ & 1.4 & 499 & $46^{* *}$ & 1.9 & 528 & $43 \dagger$ & 1.9 \\
\hline Times bred & 959 & 2.30 & 0.05 & 1,043 & $2.11^{* *}$ & 0.05 & 506 & $2.07^{* *}$ & 0.06 & 537 & 2.15 & 0.06 \\
\hline $\mathrm{DO}(\mathrm{d})$ & 901 & 125 & 2.1 & 994 & $115^{* *}$ & 2.0 & 480 & $113^{* *}$ & 2.8 & 514 & $117^{*}$ & 2.8 \\
\hline
\end{tabular}

${ }^{*}$ Significant difference $(P<0.05)$ from pure Holsteins. ${ }^{* *}$ Significant difference $(P<0.01)$ from pure Holsteins. $\dagger$ Tendency for significant difference $(P<0.10)$ from pure Holsteins. 
imposing the maximum of 250 DO provided an advantage for mean DO to the HO cows in this study. The differences between the crossbred and $\mathrm{HO}$ cows in this study were not as extreme as those found by Malchiodi et al. (2014), who reported 25 fewer DO for MO $\times$ HO versus HO cows in first lactation. Piccardi et al. (2014) observed a 30-d advantage in fewer DO for $\mathrm{VR} \times \mathrm{HO}$ compared with $\mathrm{HO}$ cows in first lactation. Malchiodi et al. (2014) reported that VR $\times$ HO cows had 13 fewer DO than pure HO cows in first lactation. Also, Heins and Hansen (2012) observed 17 and 14 fewer DO for $\mathrm{MO} \times \mathrm{HO}$ and Nordic Red $\times \mathrm{HO}$ crossbreds, respectively, versus pure $\mathrm{HO}$ cows in first lactation for highperformance commercial herds in California. Reports for DO of pure HO from other recent studies ranged from 122 to $124 \mathrm{~d}$ across multiple lactations (Bastin et al., 2010; Norman et al., 2015) and are similar to the $125 \mathrm{DO}$ of the first-lactation $\mathrm{HO}$ cows in this study. The $125 \mathrm{DO}$ of the HO cows in this study is reasonable by many standards; however, the 10-d advantage in DO for the combined crossbred cows may provide an economic advantage of $\$ 14$ to $\$ 51$ during first lactation over HO cows (Groenendaal et al., 2004; De Vries, 2006). The difference in economic advantage may result from decreased resynchronization, less culling for fertility, and a faster return to peak production at second calving.

The fertility traits of cows in this study were not adjusted for the production level of cows. Production of these cows was reported previously by Hazel et al. (2017), and the combined crossbred cows produced $2 \%$ more 305-d fat plus protein (kg; actual basis, and not mature equivalent) compared with the HO cows. Some have suggested that crossbred cows will produce less milk than pure $\mathrm{HO}$ cows and that this must be tolerated to capitalize on the advantages for fertility and other functional traits from crossbreeding (Walsh et al., 2008; Piccardi et al., 2014). However, that was not the outcome for the $\mathrm{MO} \times \mathrm{HO}$ and $\mathrm{VR} \times \mathrm{HO}$ crossbreds compared with pure $\mathrm{HO}$ cows in this study. Researchers have hypothesized that $\mathrm{HO}$ cows have been selected to preferentially partition energy to production over fertility (Sundrum, 2015). The crossbreds in this study apparently overcame physiological challenges of this sort more readily than the $\mathrm{HO}$ cows because they produced at least as much milk solids as the pure HO cows (Hazel et al., 2017) and were superior for fertility. Malchiodi et al. (2014) suggested that crossbred and HO cows may have physiological differences that allow crossbred cows to better respond to the metabolic demands of production, health, and fertility, which all occur concurrently in early lactation.

The biological reason for the superior fertility of the crossbred cows compared with the pure HO cows in this study may be partially attributable to the difference in BCS between them. Researchers (Dechow et al., 2002; Roche et al., 2009; Walsh et al., 2011) have reported that HO cows with more BCS at the time of calving or less loss in BCS after calving had increased reproductive success. Reasons for the reproductive advantages of the 2-breed crossbred cows in this study may be the advantage of the MO and VR breeds for fertility compared with the HO breed (Sørensen, 2007; Dezetter et al., 2015) and a 10\% expected heterosis for fertility when 2 unrelated pure breeds of dairy cattle are crossed (Sørensen et al., 2008).

\section{Survival}

The effect of HYS of first calving was not significant for survival to 60 DIM and subsequent calving within 14 mo, but HYS tended to be significant for subsequent calving within $17 \mathrm{mo}(P=0.09)$ and survival to second calving $(P=0.08)$. The combined crossbreds did not differ $(P=0.48)$ from HO cows for survival to 60 DIM, and $96 \pm 0.6 \%$ of both the crossbred and HO cows calving for a first time survived to 60 DIM (Table 4). The first $60 \mathrm{~d}$ after calving is a period in which cows are most at risk for health disorders (Donnelly et al., 2016) that result in removal from herds. For first-lactation cows, Dechow and Goodling (2008) found that 5\% of $\mathrm{HO}$ cows were removed from herds during the interval from $21 \mathrm{~d}$ before first calving to $60 \mathrm{~d}$ after first calving, which was similar to the $4 \%$ of both crossbred and $\mathrm{HO}$ cows that left herds. However, Heins et al. (2012) analyzed survival in first lactation from calving to the first test day for milk recording (4-30 DIM for most cows) and, despite the much shorter interval of time, only $91 \%$ of HO cows survived to a first test day compared with an increased percentage of $\mathrm{MO} \times \mathrm{HO}$ $(98 \%)$ and Nordic Red $\times$ HO $(98 \%)$. An explanation for the superior early-lactation survival of HO cows in this study compared with Heins et al. (2012) could be the increased calving difficulty of $\mathrm{HO}$ cows compared with the crossbreds in that study (Heins et al., 2006a). The crossbred cows $(1.6 \pm 0.05)$ in this study differed from $\mathrm{HO}$ cows $(1.5 \pm 0.05)$ by only a tenth of a score (on a 5-point scale) for calving difficulty at first calving (Hazel et al., 2017).

More $(P<0.01)$ of the combined crossbred cows $(71 \pm 1.5 \%)$ had a subsequent calving within 14 mo after their first calving (Table 4) compared with the HO cows $(63 \pm 1.5 \%)$. At 17 mo after first calving, the combined crossbreds $(82 \pm 1.5 \%)$ continued to surpass $(P<0.01)$ the HO cows $(76 \pm 1.4 \%)$ for subsequent calving. Traits such as subsequent calving within 14 and $17 \mathrm{mo}$ and survival to second calving revealed the more rapid speed at which the crossbreds returned to 
Table 4. Least squares means and standard errors for survival of both crossbred groups (pooled), Montbéliarde $\times$ Holstein crossbreds, and Viking Red $\times$ Holstein crossbreds compared with pure Holstein cows during first lactation

\begin{tabular}{|c|c|c|c|c|c|c|c|c|c|c|c|c|}
\hline \multirow[b]{2}{*}{ Trait } & \multicolumn{3}{|c|}{ Pure Holstein } & \multicolumn{3}{|c|}{ Both crossbred groups } & \multicolumn{3}{|c|}{$\begin{array}{c}\text { Montbéliarde } \times \\
\text { Holstein }\end{array}$} & \multicolumn{3}{|c|}{ Viking Red $\times$ Holstein } \\
\hline & $\mathrm{n}$ & LSM & SEM & $\mathrm{n}$ & LSM & SEM & $\mathrm{n}$ & LSM & SEM & $\mathrm{n}$ & LSM & SEM \\
\hline Calved again within $14 \mathrm{mo}(\%)$ & 1,021 & 63 & 1.5 & 1,082 & $71^{* *}$ & 1.5 & 530 & $72^{* *}$ & 2.1 & 552 & $70^{*}$ & 2.0 \\
\hline Calved again within $17 \mathrm{mo}(\%)$ & 1,021 & 76 & 1.4 & 1,080 & $82^{* *}$ & 1.5 & 529 & $83^{* *}$ & 2.1 & 551 & $81 \dagger$ & 2.0 \\
\hline Survival to second calving (\%) & 1,014 & 80 & 1.5 & 1,080 & $84^{*}$ & 1.5 & 529 & 84 & 2.2 & 551 & 83 & 2.1 \\
\hline
\end{tabular}

*Significant difference $(P<0.05)$ from pure Holsteins. ${ }^{* *}$ Significant difference $(P<0.01)$ from pure Holsteins. $\dagger$ Tendency for significant difference $(P<0.10)$ from pure Holsteins.

peak production compared with the HO cows. The MO $\times \mathrm{HO}$ and $\mathrm{VR} \times \mathrm{HO}$ did not differ for any measure of survival.

For survival to second calving, $4 \%$ more of the combined crossbred cows commenced a second lactation compared with HO cows (Table 4). This result was similar to those of Norman et al. (2016), who analyzed US national data and reported that $77 \%$ of crossbred cows compared with $74 \%$ of $\mathrm{HO}$ cows in first lactation calved for a second time.

\section{BCS and Conformation}

The HYS of first calving was significant for the analysis of BCS and all 10 of the conformation traits. Similarly, class of DIM at the time of scoring was significant for all traits except for STA $(P=0.16)$, LS $(P$ $=0.11)$, and FA $(P=0.17)$. Cows scored at later DIM had increased BD, decreased STR, RA with less slope, increased LS, closer FTW and RTW, and longer TL. A directional pattern for class of DIM at scoring was not observed for STA, FA, or UC. The combined crossbred cows $(3.58 \pm 0.02)$ had 0.38 increased $(P<0.01)$ BCS compared with the $\mathrm{HO}$ cows $(3.20 \pm 0.02)$ because both the $\mathrm{MO} \times \mathrm{HO}(+0.50)$ and $\mathrm{VR} \times \mathrm{HO}(+0.25)$ had increased BCS compared with HO cows (Table 5). Additionally, the $\mathrm{MO} \times \mathrm{HO}(3.70 \pm 0.02)$ had increased $(P<0.01)$ BCS compared with $\mathrm{VR} \times \mathrm{HO}$ cows $(3.45$ $\pm 0.02)$. Hazel et al. (2014) reported that $\mathrm{MO} \times \mathrm{HO}$ cows had +0.49 more BCS across lactations than HO cows. Walsh et al. (2008) had +0.23 more BCS for $\mathrm{MO} \times \mathrm{HO}$ versus $\mathrm{HO}$ cows, but the magnitude of the difference was smaller in the grazing environment of that study compared with the high-performance confinement environment of the current study. The association of low BCS with impaired fertility of cows is well documented (Roche et al., 2009; Bastin et al., 2010), and the increased BCS of crossbred cows in this study may explain some of the 10-d advantage for DO and the fewer times bred compared with HO cows. A documented close biological relationship between BCS and fertility (Dechow et al., 2002; Roche et al., 2009) precludes the use of one variable to explain variation of the other. The BCS of cows in this study was scored only once in early lactation; therefore, this study did not provide information about potential differences among the breed groups for BCS at calving, BCS at its lowest during lactation, or rate or amount of BCS lost during the transition period of lactation.

The combined crossbreds had shorter STA $(P<$ 0.01 ) than the HO cows (Table 5), and the mean scores convert to $138 \mathrm{~cm}$ for the combined crossbred cows and $141 \mathrm{~cm}$ for the HO cows (Select Sires Inc.). Also, the VR $\times$ HO $(137 \mathrm{~cm})$ had shorter STA $(P<0.01)$ than both the $\mathrm{MO} \times \mathrm{HO}$ and pure $\mathrm{HO}$ cows. The combined crossbred cows $(4.3 \pm 0.09)$ had shallower BD $(P<$ $0.01)$ compared with their HO herdmates $(5.2 \pm 0.08)$ during first lactation. The taller STA and deeper BD of the HO cows may be detrimental to the health of cows (Becker et al., 2012), which may result in advantages for survival compared with cows with smaller body size (Hansen et al., 1999). The combined crossbred cows in this study had more STR $(P<0.01)$ compared with the HO cows ( +0.7 point), but the difference was completely attributable to the greater STR of the MO $\times$ $\mathrm{HO}(+1.5$ points $)$ compared with $\mathrm{HO}$ cows, whereas the $\mathrm{VR} \times \mathrm{HO}$ cows had similar STR to the HO cows.

Both $\mathrm{MO} \times \mathrm{HO}(7.0 \pm 0.12)$ and $\mathrm{VR} \times \mathrm{HO}(6.6$ $\pm 0.11)$ had more slope $(P<0.01)$ from hips to pins for RA than HO cows $(6.1 \pm 0.07)$, and the slope was steeper $(P=0.02)$ for the $\mathrm{MO} \times \mathrm{HO}$ than for the $\mathrm{VR} \times$ HO cows. For LS, the combined crossbred cows tended $(P=0.06)$ to have less set to the hock; however, the 2 types of crossbreds were different from each other because $\mathrm{MO} \times \mathrm{HO}(4.6 \pm 0.14)$ had less set to the hock than HO cows $(5.6 \pm 0.09)$, whereas the VR $\times$ $\mathrm{HO}$ crossbreds had more set to the hock than their HO herdmates. The combined crossbred cows $(6.0 \pm 0.09)$ had steeper FA $(P<0.01)$ than the HO cows $(5.6 \pm$ $0.08)$, but the difference was entirely attributable to the 
DAIRY INDUSTRY TODAY

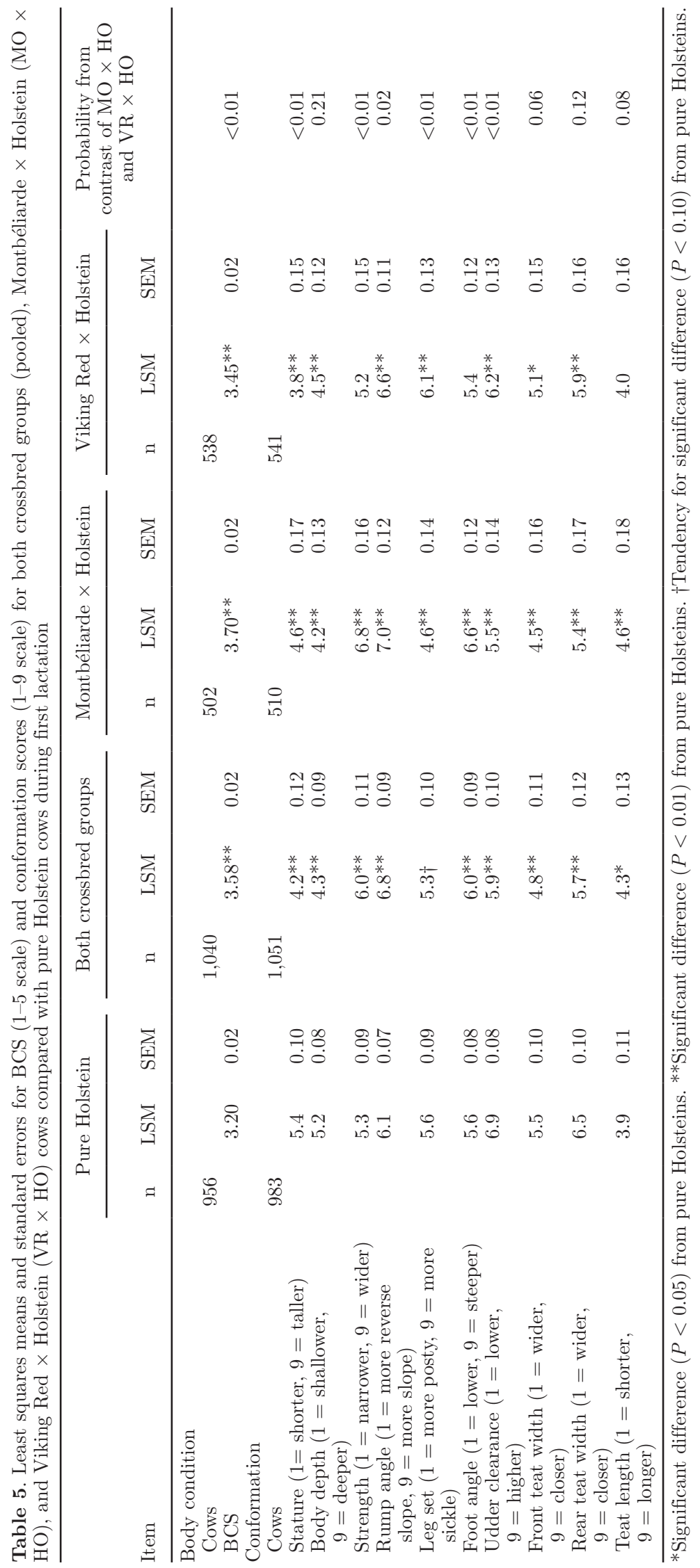


$\mathrm{MO} \times \mathrm{HO}$ cows having a 1.0-point advantage over the $\mathrm{HO}$ cows. The FA of VR $\times \mathrm{HO}(5.4 \pm 0.12)$ and $\mathrm{HO}$ cows $(5.6 \pm 0.08)$ was not different $(P=0.29)$.

For udder traits, the combined crossbred cows $(5.9 \pm$ $0.10)$ had less UC $(P<0.01)$ from the hock than the $\mathrm{HO}$ cows $(6.9 \pm 0.08)$, and the $\mathrm{MO} \times \mathrm{HO}$ cows $(5.5$ $\pm 0.14)$ had less $\mathrm{UC}(P<0.01)$ than the $\mathrm{VR} \times \mathrm{HO}$ cows $(6.2 \pm 0.13)$. The scores for UC corresponded to udders about $7.5 \mathrm{~cm}$ above the hock for the combined crossbreds and about $10 \mathrm{~cm}$ above the hock for the HO cows during first lactation for a difference of about 2.5 $\mathrm{cm}$ (Select Sires Inc.). The difference between the crossbred and $\mathrm{HO}$ cows for UC may partially be a reflection of the $3 \mathrm{~cm}$ difference for STA. Cows with shorter STA likely have shorter rear legs, which provides for less UC above the hock. The actual depth of the udders (distance from the body wall to the udder floor) may differ little between breed groups. The results from this study agree with those of Hazel et al. (2014), who objectively measured UC from the ground to the udder floor of $\mathrm{MO} \times \mathrm{HO}$ versus $\mathrm{HO}$ cows. The $\mathrm{MO} \times \mathrm{HO}$ cows had $2.6 \mathrm{~cm}$ less UC than $\mathrm{HO}$ cows across 5 parities. In that study, udders became deeper with increasing parity at approximately the same rate in each breed group. The standard errors of UC scores for both the crossbred and $\mathrm{HO}$ cows in the current study were small (0.10 and 0.08 , respectively), which suggested that very few cows had extreme scores for UC during first lactation. Cows that carry udders closer to the ground may experience more functional problems while milking or may have more contact with bedding in stalls (Hansen et al., 1999). Carlström et al. (2016a) reported that cows with less UC had increased SCS; however, the 2-breed crossbred cows in this study did not differ from HO cows for SCS during first lactation (Hazel et al., 2017).

The FTW was wider $(P<0.01)$ for the crossbred $(4.8 \pm 0.11)$ than the HO cows $(5.5 \pm 0.10)$. Close FTW is generally regarded as favorable for functional milking. Also, RTW was wider $(P<0.01)$ for the crossbred $(5.7 \pm 0.12)$ than the HO cows $(6.5 \pm 0.10)$. The mean RTW of the first-lactation HO cows in this study was +1.5 points closer than the 5 -point intermediate optimum, and close RTW is especially problematic for automated milking systems. Farmers in Ontario, Canada, reported that the attachment sensor for automated milking systems may consider the 2 rear teats to be a single teat when cows have close RTW, and this problem resulted in up to $3 \%$ additional culling (Rodenburg, 2002). Therefore, the wider RTW of the crossbred cows compared with the HO cows in this study may have functional advantages for milking.

The TL was longer $(P<0.01)$ for the crossbred cows $(4.3 \pm 0.13)$ compared with their HO herdmates $(3.9$ \pm 0.11 ), and the difference was entirely attributable to the longer TL of the $\mathrm{MO} \times \mathrm{HO}$ cows $(4.6 \pm 0.18)$ because the VR $\times \mathrm{HO}$ cows did not differ from the HO cows. Historical selection for shorter TL was motivated by a desire for faster milking speeds, but very short TL may be a problem for teat cup attachment (Carlström et al., 2016b). Based on the conversion of linear scores to a metric scale, the mean TL of $\mathrm{HO}$ cows in this study was $5 \mathrm{~cm}$, and TL of the crossbred cows were $0.5 \mathrm{~cm}$ longer than those of the HO cows. Furthermore, $16 \%$ of $\mathrm{HO}$ cows had very short TL (score of 1 on a 9-point scale) compared with fewer $(P<0.03)$ of the MO $\times$ HO cows (11\%). A chi-squared test indicated that the proportion of cows culled for udder conformation during first lactation in this study did not differ $(P=0.87)$ between the crossbred (7 of 1,080 cows) and HO cows (6 of 1,014 cows). Therefore, differences between breed groups for udder traits during first lactation may not have practical consequence.

\section{Implications for the Industry}

The results of this study are informative for high-performance dairy herds that seek improvement of fertility and survival of their cows without loss of production. A limitation of this study is that the results are from cows managed only in high-performance dairy herds in the upper Midwest of the United States. Results may be different for cows provided lower management levels or located in other environments globally.

The 2-breed crossbred cows in this study had shorter STA and shallower BD than their HO herdmates, and this may have provided benefits for cow health and production efficiency. In the future, cows in this study will contribute to a comprehensive economic comparison of the crossbred versus $\mathrm{HO}$ cows in the 8 herds that will include revenues and expenses from production, salvage value of cows, value of calves, cost of replacements, feed intake, fertility, and cost of health disorders. The first generation of crossbred cows examined in this designed study is only a single generation at the initiation of a rotational crossbreeding program. Therefore, subsequent generations of crossbred cows must be studied to assess the long-term consequences of 3-breed rotational crossbreeding.

\section{ACKNOWLEDGMENTS}

The authors express gratitude to the 8 dairy herd owners and managers for their participation in this study and for providing data on the cows in their herds. The authors also thank Minnesota Select Sires Co-op Inc. (St. Cloud, MN) for its contributions of mating individual heifers and cows with AI bulls and the scoring of BCS and conformation traits. Funding for this 
project was provided by Coopex Montbéliarde (Roulans, France), Viking Genetics (Randers, Denmark), Creative Genetics of California (Oakdale, CA), Select Sires Inc. (Plain City, OH), and Minnesota Select Sires Co-op Inc.

\section{REFERENCES}

Alvåsen, K., M. Jansson Mörk, C. Hallén Sandgren, P. T. Thomsen, and U. Emanuelson. 2012. Herd-level risk factors associated with cow mortality in Swedish dairy herds. J. Dairy Sci. 95:4352-4362. https://doi.org/10.3168/jds.2011-5085.

Bastin, C., S. Loker, N. Gengler, A. Sewalem, and F. Miglior. 2010. Genetic relationships between body condition score and reproduction traits in Canadian Holstein and Ayrshire first-parity cows. J. Dairy Sci. 93:2215-2228. https://doi.org/10.3168/jds.2009-2720.

Becker, J. C., B. J. Heins, and L. B. Hansen. 2012. Costs for health care of Holstein cows selected for large versus small body size. J. Dairy Sci. 95:5384-5392. https://doi.org/10.3168/jds.2012-5344.

Berry, D. P., E. Wall, and J. E. Pryce. 2014. Genetics and genomics of reproductive performance in dairy and beef cattle. Animal 8:105-121. https://doi.org/10.1017/S1751731114000743.

Bourrigan, X., S. Mattalia, C. Bouissel, R. Dremaux, M. Dupres, J. J. Evard, X. Gouraud, M. Legay, L. Maurin, B. Schmitt, J. M. Gautier, P. Roussel, and G. Blériot. 2016. French health recording systems: Possible new valorizations of events recorded by farmers. Pages 177-182 in Proc. 40th ICAR Biennial session, Puerto Varas, Chile. ICAR, Rome, Italy.

Carlström, C., E. Strandberg, K. Johansson, G. Pettersson, H. Stålhammar, and J. Philipsson. 2016a. Genetic associations of in-line recorded milkability traits and udder conformation with udder health. Acta Agric. Scand. Anim. Sci. 66:84-91. https://doi.org/ 10.1080/09064702.2016.1260154.

Carlström, C., E. Strandberg, G. Pettersson, K. Johansson, H. Stålhammar, and J. Philipsson. 2016b. Genetic associations of teat cup attachment failures, incomplete milkings, and handling time in automatic milking systems with milkability, temperament, and udder conformation. Acta Agric. Scand. Anim. Sci. 66:75-83. https://doi .org/10.1080/09064702.2016.1260153.

Council on Dairy Cattle Breeding. 2017. Trend in inbreeding coefficients of cows for Holstein or Red and White. Accessed May 24, 2017. https://www.uscdcb.com/eval/summary/inbrd.cfm.

De Vries, A. 2006. Determinants of the cost of days open in dairy cattle. Pages 1114-1115 in 11th International Symposium on Veterinary Epidemiology and Economics, Cairns, Australia.

Dechow, C. D., and R. C. Goodling. 2008. Mortality, culling by sixty days in milk, and production profiles in high- and low-survival Pennsylvania herds. J. Dairy Sci. 91:4630-4639. https://doi.org/ 10.3168/jds.2008-1337.

Dechow, C. D., G. W. Rogers, and J. S. Clay. 2002. Heritability and correlations among body condition score loss, body condition score, production and reproductive performance. J. Dairy Sci. 85:30623070. https://doi.org/10.3168/jds.S0022-0302(02)74393-2.

Dezetter, C., H. Leclerc, S. Mattalia, A. Barbat, D. Boichard, and V. Ducrocq. 2015. Inbreeding and crossbreeding parameters for production and fertility traits in Holstein, Montbéliarde, and Normande cows. J. Dairy Sci. 98:4904-4913. https://doi.org/10.3168/ jds.2014-8386.

Donnelly, M. R., A. R. Hazel, B. J. Heins, and L. B. Hansen. 2016. Health treatment costs of pure Holsteins in 8 high-performance Minnesota dairies. J. Dairy Sci. 99(E-Suppl. 1):1242. (Abstr.)

Emanuelson, U. 2013. Validation of the Nordic disease databases. Pages 101-107 in ICAR Technical Series no. 17, Aarhus, Denmark. ICAR, Rome, Italy.

Falconer, D. S., and T. F. C. Mackay. 1996. Introduction to Quantitative Genetics. 4th ed. Longman House, Harlow, UK.

Ferguson, J. D., D. T. Galligan, and N. Thomsen. 1994. Principal descriptors of body condition score in Holstein cows. J. Dairy Sci.
77:2695-2703. https://doi.org/10.3168/jds.S0022-0302(94)77212 $-\mathrm{X}$.

Groenendaal, H., D. T. Galligan, and H. A. Mulder. 2004. An economic spreadsheet model to determine optimal breeding and replacement decisions for dairy cattle. J. Dairy Sci. 87:2146-2157. https://doi.org/10.3168/jds.S0022-0302(04)70034-X.

Gröhn, Y. T., P. J. Rajala-Schultz, H. G. Allore, M. A. DeLorenzo, J. A. Hertl, and D. T. Galligan. 2003. Optimizing replacement of dairy cows: Modeling the effects of diseases. Prev. Vet. Med. 61:27-43. https://doi.org/10.1016/S0167-5877(03)00158-2.

Hansen, L. B. 2000. Symposium: Selection for milk yield. Consequences of selection for milk yield from a geneticist's viewpoint. J. Dairy Sci. 83:1145-1150. https://doi.org/10.3168/jds.S0022 -0302(00)74980-0.

Hansen, L. B., J. B. Cole, G. D. Marx, and A. J. Seykora. 1999. Productive life and reasons for disposal of Holstein cows selected for large versus small body size. J. Dairy Sci. 82:795-801. https://doi .org/10.3168/jds.S0022-0302(99)75298-7.

Hare, E., H. D. Norman, and J. R. Wright. 2006. Survival rates and productive herd life of dairy cattle in the United States. J. Dairy Sci. 89:3713-3720. https://doi.org/10.3168/jds.S0022 $-0302(06) 72412-2$

Hazel, A. R., B. J. Heins, and L. B. Hansen. 2017. Production and calving traits of Montbeliarde $\times$ Holstein and Viking Red $\times$ Holstein crossbred cows compared with pure Holstein cows during first lactation in 8 commercial dairy herds. J. Dairy Sci. 100:41394149. https://doi.org/10.3168/jds.2016-11860.

Hazel, A. R., B. J. Heins, A. J. Seykora, and L. B. Hansen. 2013. Montbéliarde-sired crossbreds compared with pure Holsteins for dry matter intake, production, and body traits during the first 150 days of first lactation. J. Dairy Sci. 96:1915-1923. https://doi.org/ $10.3168 /$ jds.2012-5667.

Hazel, A. R., B. J. Heins, A. J. Seykora, and L. B. Hansen. 2014. Production, fertility, survival, and body measurements of Montbéliarde-sired crossbreds compared with pure Holsteins during their first 5 lactations. J. Dairy Sci. 97:2512-2525. https://doi.org/10 .3168/jds.2013-7063.

Heins, B. J., and L. B. Hansen. 2012. Short communication: Fertility, somatic cell score, and production of Normande $\times$ Holstein, Montbéliarde $\times$ Holstein, and Scandinavian Red $\times$ Holstein crossbreds versus pure Holsteins during their first 5 lactations. J. Dairy Sci. 95:918-924. https://doi.org/10.3168/jds.2011-4523.

Heins, B. J., L. B. Hansen, and A. De Vries. 2012. Survival, lifetime production, and profitability of crossbreds of Holstein with Normande, Montbéliarde, and Scandinavian Red compared to pure Holstein cows. J. Dairy Sci. 95:1011-1021. https://doi.org/10 $.3168 /$ jds.2011-4525.

Heins, B. J., L. B. Hansen, and A. J. Seykora. 2006a. Calving difficulty and stillbirths of pure Holsteins versus crossbreds of Holstein with Normande, Montbeliarde, and Scandinavian Red. J. Dairy Sci. 89:2805-2810. https://doi.org/10.3168/jds.S0022-0302(06)72357 $-8$.

Heins, B. J., L. B. Hansen, and A. J. Seykora. 2006b. Fertility and survival of pure Holsteins versus crossbreds of Holstein with Normande, Montbeliarde, and Scandinavian Red. J. Dairy Sci. 89:4944-4951. https://doi.org/10.3168/jds.S0022-0302(06)72545 $-0$.

Kyntäjä, J. 2013. Health data recording in Finland. Pages 83-85 in ICAR Technical Series no. 17, Aarhus, Denmark. ICAR, Rome, Italy.

Malchiodi, F., A. Cecchinato, and G. Bittante. 2014. Fertility traits of purebred Holsteins and 2- and 3-breed crossbred heifers and cows obtained from Swedish Red, Montbéliarde, and Brown Swiss sires. J. Dairy Sci. 97:7916-7926. https://doi.org/10.3168/jds.2014 -8156 .

Miglior, F., B. L. Buir, and B. J. Van Doormaal. 2005. Selection indices in Holstein cattle of various countries. J. Dairy Sci. 88:12551263. https://doi.org/10.3168/jds.S0022-0302(05)72792-2.

Montbéliarde, O. S. 2016. The Unique Synthesis Index (ISU), the steering tool of the Montbeliarde selection. Accessed May 4, 2016. http://www.montbeliarde.org/en-428.html. 
Nordic Cattle Genetic Evaluation. 2016. NTM-Nordic total merit. Accessed Jun. 6, 2016. http://www.nordicebv.info/en/ntm-nordic -total-merit-2/.

Norman, H. D., L. M. Walton, and J. Dürr. 2015. Reproductive status of cows in dairy herd improvement programs and bred using artificial insemination (2014). Accessed Mar. 2, 2017. https://www .uscdcb.com/publish/dhi/current/reproall.html.

Norman, H. D., L. M. Walton, and J. Dürr. 2016. Reasons that cows in dairy herd improvement programs exit the milk herd. Accessed Mar. 2, 2017. https://www.uscdcb.com/publish/dhi/current/ cullall.html.

Norman, H. D., J. R. Wright, S. M. Hubbard, R. H. Miller, and J. L. Hutchison. 2009. Reproductive status of Holstein and Jersey cows in the United States. J. Dairy Sci. 92:3517-3528. https://doi.org/ 10.3168/jds.2008-1768.

Philipsson, J., G. Banos, and T. Arnason. 1994. Present and future uses of selection index methodology in dairy cattle. J. Dairy Sci 77:3252-3261. https://doi.org/10.3168/jds.S0022-0302(94)77266 -0 .

Piccardi, M., D. Pipino, G. A. Bó, and M. Balzarini. 2014. Productive and reproductive performance of first lactation purebred Holstein versus Swedish Red and White $\times$ Holstein in central Argentina. Livest. Sci. 165:37-41. https://doi.org/10.1016/j.livsci.2014.04 .025 .

Pryce, J. E., and B. L. Harris. 2006. Genetics of body condition score in New Zealand dairy cows. J. Dairy Sci. 89:4424-4432. https:// doi.org/10.3168/jds.S0022-0302(06)72490-0.

Raboisson, D., E. Cahuzac, P. Sans, and G. Allaire. 2011. Herd-level and contextual factors influencing dairy cow mortality in France in 2005 and 2006. J. Dairy Sci. 94:1790-1803. https://doi.org/10 $.3168 /$ jds.2010-3634.

Roche, J. R., N. C. Friggens, J. K. Kay, M. W. Fisher, K. J. Stafford, and D. P. Berry. 2009. Invited review: Body condition score and its association with dairy cow productivity, health, and welfare. J. Dairy Sci. 92:5769-5801. https://doi.org/10.3168/jds.2009-2431.

Rodenburg, J. 2002. Robotic milkers: What, where... and how much!!?? Pages 1-18 in Proc. Ohio Dairy Management Conf., Columbus, OH. Ohio State University Extension, Columbus.

Sørensen, M. K. 2007. Crossbreeding-An important part of sustainable breeding in dairy cattle and possibilities for implementation.
Pages 29-40 in Crossbreeding of Dairy Cattle: The Science and the Impact. 4th Biennial W. E. Petersen Symposium, St. Paul, MN. Department of Animal Science, University of Minnesota, St. Paul. Sørensen, M. K., E. Norberg, J. Pedersen, and L. G. Christensen. 2008 Invited review: Crossbreeding in dairy cattle: A Danish perspective. J. Dairy Sci. 91:4116-4128. https://doi.org/10.3168/jds.2008 -1273 .

Sundrum, A. 2015. Metabolic disorders in the transition period indicate that the dairy cows' ability to adapt is overstressed. Animals (Basel) 5:978-1020. https://doi.org/10.3390/ani5040395.

VandeHaar, M. J., L. E. Armentano, K. Weigel, D. M. Spurlock, R. J. Templeman, and R. Veerkamp. 2016. Harnessing the genetics of the modern dairy cow to continue improvements in feed efficiency. J. Dairy Sci. 99:4941-4954. https://doi.org/10.3168/jds .2015-10352.

VanRaden, P. M., and J. B. Cole. 2014. AIP research report NM $\$ 5$. Net merit as a measure of lifetime profit: 2014 revision. Accessed Jun. 6, 2016. http://aipl.arsusda.gov/reference/nmcalc-2014.htm.

VanRaden, P. M., A. H. Sanders, M. E. Tooker, R. H. Miller, H. D Norman, M. T. Kuhn, and G. R. Wiggans. 2004. Development of a national genetic evaluation for cow fertility. J. Dairy Sci. 87:22852292. https://doi.org/10.3168/jds.S0022-0302(04)70049-1.

VanRaden, P. M., M. E. Tooker, J. R. Wright, J. B. Cole, D. J. Null, and T. J. Lawlor. 2014. AIP Research Report BASE3: Genetic base changes for December 2014. Accessed Jul. 26, 2016. http:// aipl.arsusda.gov/reference/base2014.htm.

Walsh, S., F. Buckley, K. Pierce, N. Bryne, J. Patton, and P. Dillon 2008. Effects of breed and feeding system on milk production body weight, body condition score, reproductive performance, and postpartum ovarian function. J. Dairy Sci. 91:4401-4413. https:// doi.org/10.3168/jds.2007-0818.

Walsh, S. W., E. J. Williams, and A. C. O. Evans. 2011. A review of the causes of poor fertility in high milk producing dairy cows Anim. Reprod. Sci. 123:127-138. https://doi.org/10.1016/j .anireprosci.2010.12.001.

Zwald, N. R., K. A. Weigel, Y. M. Chang, R. D. Welper, and J. S. Clay 2004. Genetic selection for health traits using producer-recorded data. II. Genetic correlations, disease probabilities, and relationships with existing traits. J. Dairy Sci. 87:4295-4302. https://doi .org/10.3168/jds.S0022-0302(04)73574-2. 